\title{
Pemberdayaan ekonomi masyarakat rentan pasca kondisi new normal pada daerah rawan kebakaran hutan dan lahan gambut di Kabupaten Siak
}

\author{
Ashaluddin Jalil, Yesi*, \& Seger Sugiyanto \\ Universitas Riau \\ * yesi.y@lecturer.unri.ac.id
}

\begin{abstract}
Abstrak. Ekonomi masyarakat di kawasan rawan kebakaran hutan dan lahan pasca new normal sangat terguncang karena krisis covid-19 dan musim kemarau. Pengabdian ini dilakukan di Kampung Rawa Mekar Jaya Kabupaten Siak dengan rtujuan menciptakan ketahanan ekonomi masyarakat yang tinggal di kawasan rawan kebakaran hutan dan lahan dengan mengelola gambut menggunakan cara yang ramah lingkungan atau tidak menggunakan api. Metode pengabdian diawali persiapan dan pelaksanaan dengan melibatkan unsur mahasiswa dan masyarakat setempat. Kegiatan pengabdian yang dilaksankan antara lain budidaya ikan lele dan penanaman Tanaman Obat Keluarga atau TOGA. Ketercapaian pengabdian dilihat dari antusias masyarakat mengikuti seluruh proses yang dilakukan mulai dari diskusi hingga aksi lapangan. Sementara kendala pengabdian diantaranya disebabkan oleh covid-19 yang membuat waktu dan pergerakan terbatas serta mengharuskan pengaturan ulang rencana program.
\end{abstract}

Kata kunci: pemberdayaan ekonomi, kebakaran hutan, lahan, masyarakat rentan

\begin{abstract}
The economy of people in areas prone to forest and land fires after the new normal is very shaken because of the Covid-19 crisis and the dry season. This service was carried out in Kampung Rawa Mekar Jaya, Siak Regency with the aim of creating economic resilience for people living in areas prone to forest and land fires by managing peat using environmentally friendly methods or not using fire. The service method begins with preparation and implementation by involving elements of students and the local community. The community service activities include catfish farming and planting of family medicinal plants or TOGA. The achievement of community service can be seen from the enthusiasm of the community in participating in the entire process, from discussions to field actions. Meanwhile, service constraints were caused by covid-19, which limited time and movement and required rearranging program plans.
\end{abstract}

Keywords: economic empowerment, forest and land fires, vulnerable communities

To cite this article: Jalil, A., Yesi, \& S. Sugiyanto. 2020. Pemberdayaan ekonomi masyarakat rentan pasca kondisi new normal pada daerah rawan kebakaran hutan dan lahan gambut di Kabupaten Siak. Unri Conference Series: Community Engagement 2: 531-536. https://doi.org/10.31258/unricsce.2.531-536

(C) 2020 Authors

Peer-review under responsibility of the organizing committee of Seminar Nasional Pemberdayaan Masyarakat 2020 


\section{PENDAHULUAN}

Di saat belum ditemukannya vaksin untuk mengatasi pandemic Covid-19 kita dihadapkan bahwa musim kemarau panjang akan segera datang. Hal ini menjadi sebuah persoalan tersendiri untuk masyarakat yang tinggal di daerah rawan kebakaran hutan dan lahan. Mereka akan menghadapi dua situasi yang sama-sama merugikan segi sosial maupun ekonomi. Badan Meteorologi, Klimatologi dan Geofisika (BMKG) dalam keterangannya telah menyampaikan bahwa musim kemarau di Indonesia akan mencapai puncak pada bulan Agustus hingga September dan secara umum untuk saat ini wilayah Riau, Sumatera Utara dan Jambi sudah memasuki musim kemarau (Saturi, 2020).

Situasi yang terjadi sekarang di kawasan rawan kebakaran sudah menunjukkan intensitas yang serius dimana lahan sudah semakin kering sementara hujan mulai berkurang. Kebakaran juga terjadi dimana-mana, seperti yang dikatakan Kepala Badan Penanggulangan Bencana Daerah (BPBD) Provinsi Riau, sejak awal Januari hingga maret sudah 797,53 ha lahan terbakar dibeberapa kabupaten/kota diantaranya Rokan Hilir 35,25 ha, Kota Dumai 98,55 ha, Bengkalis 162,1 ha, Kepulauan Meranti 24 ha, Kampar 19,37 ha, Siak 165,06 ha, Pekanbaru 10 ha, Pelalawan 22,6 ha, Indragiri Hulu 45 ha, dan Indragiri Hilir 215,6 ha (Dewi, 2020).

Secara umum hampir seluruh kabupaten/kota di semester pertama tahun 2020 sudah mengalami kebakaran hutan dan lahan. Padahal pada periode tersebut curah hujan masih tergolong normal, tetapi sekali lagi bahwa peristiwa kebakaran hutan dan lahan dapat disebabkan oleh banyak hal termasuk kondisi lahan yang sudah kritis. Sehingga sebagai solusi untuk mengatasi agar dampak sosial ekonomi dari Covid-19 tidak semakin parah dengan adanya kebakaran hutan dan lahan yang sewaktu-waktu terjadi diperlukan adanya penguatan ekonomi. Model penguatan ekonomi pada masyarakat rentan dapat dilakukan melalui pemberdayaan dengan pemanfaatan potensi yang ada. Masyarakat rentan adalah mereka yang berada pada tingkatan ekonomi menengah bawah yang mendapatkan penghasilan dari pekerjaannya tersebut dalam batas minimal cukup untuk memenuhi kebutuhan hidup beberapa hari saja harus diprioritaskan agar keadaan ekonominya tidak semakin terpuruk. Fokus pengabdian ini berada di lokasi Kampung Rawa Mekar Jaya Kecamatan Sungai Apit Kabupaten Siak. Sesungguhnya ini bukanlah lokasi pertama yang dijadikan fokusp pengabdian. Pada awalnya kegiatan pengabdian disusun untuk dilakukan di Desa Lukun Kabupaten Kepulauan Meranti. Namun, karena situasi pandemic yang semakin mengganas dan mempertimbangkan masalah kesehatan tersebut maka lokasi dipindahkan ke Kampung Rawa Mekar Jaya yang sama-sama menjadi kawasan rawan kebakaran hutan dan lahan. Umumnya masyarakat dominan bekerja di sektor pertanian baik tanaman musiman maupun tahunan. Kampung yang tergolong baru dan dimekarkan pada tahun 2008 ini memiliki penduduk 1010 yang tersebar di dua dusun dengan suku dominan Jawa dan Melayu.

Tabel Distribusi Jumlah KK Berdasarkan Jenis Mata Pencaharian

\begin{tabular}{|c|c|c|}
\hline No & Mata Pencaharian & Jumlah KK \\
\hline 1 & Petani & 80 \\
\hline 2 & Pedagang/Swasta & 35 \\
\hline 3 & PNS & 5 \\
\hline
\end{tabular}

Sumber: Profil Rawa Mekar Jaya, 2018.

Ada sekitar 80 Kepala Keluaga petani yang menggantungkan hidup dari sektor pemanfaatan gambut untuk komoditas diantaranya nanas, palawija, karet, dan sawit juga tanaman lainnya. Saat ini situasi sulit dari sisi ekonomi juga dirasakan oleh mereka. Baik karena pandemic covid-19 maupun adanya musim kemarau. Pandemic covid-19 telah menyabkan beban ekonomi rumah tangga semakin besar seperti kebutuhan pokok sandang, pangan dan papan termasuk masalah kesehatan. Di sisi lain kemarau juga menjadi gangguan bagi mereka dalam bekerja. Maka dalam posisi demikian ekonomi rumah tangga benar-benar diterpa badai. Kita mendukung adanya kemapanan secara ekonomi tanpa merusak ekosistem gambut. Atas dasar pemenuhan kebutuhan ekonomi kita juga tidak ingin ada masyarakat yang mengelola lahan gambut menjadi tidak terkendali dan menjarah hutan tanpa pertimbangan bahwa hal itu dapat membahayakan ekosistem di mana mereka tinggal. Pertimbangan inilah yang kemudian menjadi satu alasan mengapa pengabdian ini pada akhirnya dilakukan di Kampung Rawa Mekar Jaya dengan mengusung tema pemberdayaan ekonomi pada masyarakat rentan di daerah rawan kebakaran hutan dan lahan. Tema ini sengaja dipilih karena posisi mereka memang masyarakat rentan. Makna rentan disini dapat ditafsirkan berbeda-beda, tetapi tim berpedoman pada 
kerentanan sosial ekonomi seperti kemiskinan dan ketidakberdayaan yang diakibatkan adanya suatu keadaan saat ini yakni pandemic covid-19 dan musim kemarau.

\section{Tinjauan pustaka}

1. Pemberdayaan masyarakat dalam perspektif sosiologis

Penggunaan istilah pemberdayaan merujuk pada sebuah pengertian mengerahkan seluruh sumber daya untuk mendukung masyarakat berkembang dan bergerak dari suatu keadaan yang sulit terutama menyangkut ekonomi. Konsep ini merujuk pada usaha untuk menguatkan posisi seseorang atau rumah tangga yang biasanya berada di kawasan pedesaan. Pemberdayaan bukanlah istilah baru, melainkan suatu upaya untuk menungkatkan kemampuan dan potensi yang dimiliki oleh suatu masyarakat sehingga mereka dapat mengaktualisasikan jati diri, hasrat dan martabatnya secara maksimal untuk bertahan dan mengembangkan diri secara mandiri (Fauziah, 2009).

Tidak mudah untuk mencapai masyarakat yang berdaya secara sosial-ekonomi. Ada tahapan panjang yang harus dilalui karena sering sekali pemberdayaan ini terbentur pada regulasi hulu hingga hilir. Proses pemberdayaan merupakan sebuah langkah tahap demi tahapan yang panjang dengan berusaha untuk bergerak secara dinamis mengikuti dinamika kehidupan sosial ekonomi masyarakat. Pemberdayaan membutuhkan kerjasama seluruh pihak dan harus dilakukan bertahap karena esensinya adalah menginginkan masyarakat untuk mengadopsi suatu konsep maupun teknologi terapan dalam kehidupan sehari-hari mereka. Pada prosesnya yang dilakukan adalah membangun kemampuan masyarakat, dengan memberikan dorongan, membangkitkan kesadaran akan potensi yang mereka miliki serta berupaya untuk mengembangkan potensi itu menjadi sebuah tindakan yang nyata melalui berbagai strategi dan pendekatan (Zubaedy, 2013).

2. Strategi pemberdayaan masyarakat

Program pemberdayaan tidak hanya sekedar program terapan yang ingin dilakukan atau diadopsi oleh masyarakat. Yang dilihat dari proses prmberdayaan tersebut dan menjadi bagian paling vital adalah mengenai strategi pemberdayaannya. Proses pemberdayaan masyarakat kerap kali dilakukan melalui pendekatan kelompok dimana ada saling membagi informasi mengenai pengalaman-pengalaman tertentu. pelaksanaannya melalui tahapan-tahapan yang disusun secara sistematis dan merupakan proses kegiatan yang diulang terusmenerus.

Adapun strategi pemberdayaan terdiri dari dua macam, yaitu:

a. Pemberdayaan sebagai sebuah proses

Adalah serangkaian kegiatan untuk memperkuat kekuasaan atau keberdayaan kelompok lemah dalam masyarakat termasuk individu-individu yang mengalami kemiskinan.

b. Pemberdayaan sebagai sebuah tujuan

Merujuk pada keadaan atau hasil yang ingin dicapai oleh sebuah perubahan sosial yaitu masyarakat yang berdaya, memiliki kekuasaan atau memiliki kemampuan dalam memenuhi kebutuhan hidupnya baik fisik, ekonomi maupun sosial seperti kepercayaan diir, kemampuan menyampaikan aspirasi, mempunyai mata pencaharian, berpartisipasi dalam kegiatan sosial dan mandiri dalam melaksanakan tugas yang dimiliki (Prijono, 2001).

\section{METODE PENERAPAN}

Untuk mengimpelentasikan program pengabdian maka tim melakukan beberapa tahapan, diantaranya:

1. Persiapan

a. Membentuk kerja sama dengan aparat desa setempat.

b. Membentuk kerjasama dengan pengisi materi (dari pihak akademisi-Universitas/Dosen).

c. Menyiapkan materi pengabdian.

2. Pelaksanaan

a. Sosialisasi kepada masyarakat Kampung Rawa Mekar Jaya mengenai ketahanan ekonomi rumah tangga melalui budidaya ikan lele dumbo dan tanaman obat keluarga atau TOGA.

b. Melibatkan seluruh unsur kelembagaan lokal dan masyarakat serta memberikan rekomendasi pada penentuan langkah dalam penyuluhan selanjutnya oleh pihak terkait. 


\section{HASIL DAN KETERCAPAIAN SASARAN}

\section{Budidaya Ikan Lele Dumbo}

Satu jenis ikan yang termasuk kategori popular pada masyarakat Indonesia adalah ikan lele. Peminatnya tersebar merata dari kota hingga pelosok desa. Selain kadungan gizi yang tinggi, lele juga relatif mudah untuk dibudidayakan dengan berbagai teknik budidaya seperti kolam, jaring tancap, dan jenis pembudidayaan lain. Lele juga termasuk komoditas perikanan yang mudah diolah menjadi apa saja tidak hanya terbatas pada pemanfaatan dagingnya tetapi juga bagian lain seperti sisik, tulang, sirip kepala, jeroan, dan bagian kepala ikan yang dapat diolah menjadi tepung untuk diaplikasikan ke produk olahan panganan agar menambah cita rasa yang lebih lezat (Apriyana, 2014).

Tidak hanya itu saja, secara khusus lele termasuk ikan yang baik untuk kesehatan. Tim melakukan pengabdian dengan pembudidayaan ikan lele dumbo dengan dengan alasan bahwa produk lele jenis ini diminati karena ukurannya yang cenderung besar juga bergading tebal. Di Rawa Mekar Jaya beberapa orang sudah pernah memiliki pengalaman dalam membudidayakan ikan lele dan jenis lainnya dan mereka mengatakan bahwa penjualan lele di kampung tersebut relatif mudah tetapi produk dijual tidak dalam keadaan terolah melainkan masih hidup. Di lokasi pengabdian ikan lele yang dibudidayakan sengaja disebar ke beberapa orang yang dianggap mampu menularkan virus budidaya kepada masyarakat lain. Mereka bukan saja sosok yang dianggap mampu untuk mengajak orang lain melakukan budidaya tetapi juga orang yang sebelumnya pernah membudidayakan ikan termasuk lele. Sehingga dari segi pengetahuan mengenai perawatan ikan dapat dikatakan orang-orang yang dituju untuk terlibat langsung dalam kegiatan pengabdian ini merupakan orang yang pandai.

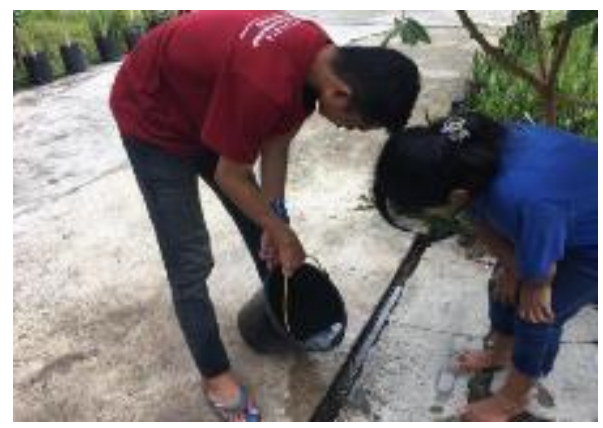

Gambar 1. Proses Pengecekan Benih Lele Dumbo

Sumber: Dokumentasi Lapangan, 2020.

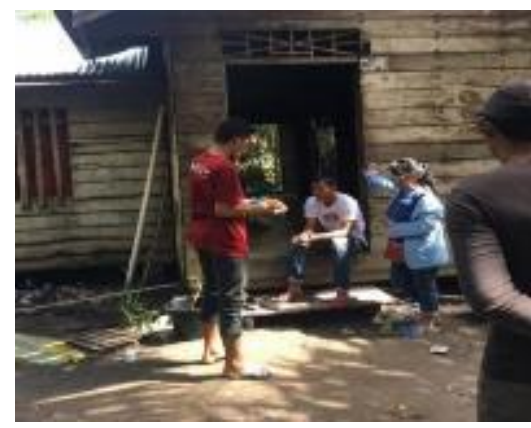

Gambar 2. Distribusi Benih Lele pada Masyarakat

Sumber: Dokumentasi Lapangan, 2020.

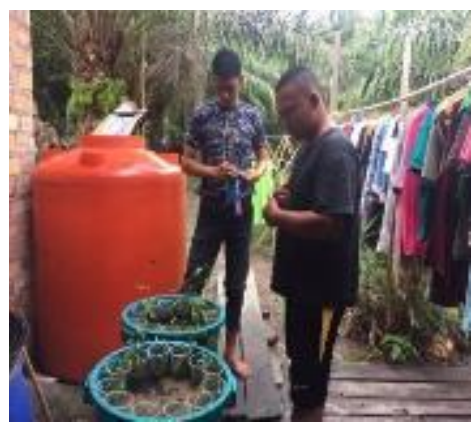

Gambar 3. Distribusi Benih Lele dan Model Budidaya Skala Kecil Menggunakan Ember Bekas

Sumber: Dokumentasi

Lapangan, 2020.

Mengingat ini merupakan pengabdian terintegrasi maka seluruh rangkaian kegiatan melibatkan partisipasi aktif mahasiswa yang melakukan Kuliah Kerja Nyata di wilayah tersebut sebanyak 10 orang dengan mahasiswa yang berasal dari background perikanan berjumlah 1 orang. Di lokasi tim membagikan lebih kurang 500 benih ikan lele kepada 5 Kepala Keluarga sebagai perwakilan masyarakat. Sesuai dengan kriteria yang telah disebutkan di atas bahwa mereka dipilih berdasarkan beberapa pertimbangan maka tim berharap untuk selanjutnya kegiatan ini akan berhasil hingga tahapan panen. Berkaitan dengan hal tersebut secara khusus respon masyarakat baik yang diberikan amanah untuk membudidayakan maupun yang tidak cukup antusias bahkan diantara mereka ada yang sengaja menawarkan bekas kolam untuk dijadikan tempat penaburan benih dan dikelola bersama.

\section{Budidaya Tanaman Obat Keluarga (TOGA)}

Istilah Tanaman Obat Keluarga (TOGA) sudah tidak asing lagi bagi masyarakat di Indonesia terutama di tingkat daerah. Tanaman Obat Keluarga atau yg biasa di sebut apotik hidup merupakan tanaman yang memiliki fungsi sebagai obat herbal dan ditanam dipekarangan atau kebun milik warga. Tanaman TOGA sering dimanfaakan oleh masyarakat sebagai obat tradisional karena selain harganya yang cukup murah juga tidak menimbulkan efek samping bagi kesehatan. Sedangkan tanaman obat sendiri adalah tanaman yang sebagian 
atau seluruh tanamannya dimanfaatkan sebagai obat, bahan atau ramuan obat (Nugraha \& Agustiningsih, 2015).

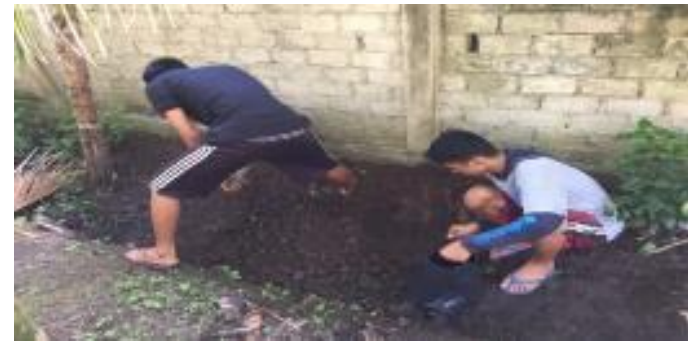

Gambar 4. Proses Pencampuran Tanah Sumber: Dokumentasi Lapanga, 2020.

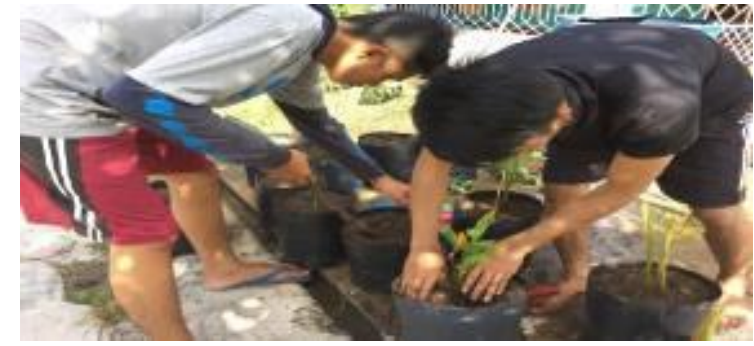

Gambar 5. Penanaman TOGA dengan polybag Sumber: Dokumentasi Lapangan, 2020.

Tim pengabdian menanam beberapa jenis obat-obatan yang berfungsi ganda, selain sebagai obat juga dapat digunakan sebagai bumbu aneka olahan makanan. Hal ini ditujukan untuk mendapatkan dua manfaat sekaligus pada situasi pandemic seperti ini yakni kesehatan yang paling utama dan ekonomi menjadi bagian selanjutnya. Beberapa tanaman yang ditanam antara lain kunyit putih, kunyit, jerangau dan serai. Masing-masing tanaman ini memiliki khasiat yang baik untuk kesehatan sekaligus dapat dimanfaatkan untuk produk olahan kuliner. Beberapa penggunaan tanaman-tanaman tersebut oleh masyarakat sekitar diantaranya sebagai obat masuk angin, pegal-pegal, radang tenggorokan, perut kembung, sakit kepala, demam, batuk, dan sebagainya. Sementara penggunaan untuk produk makanan seperti bumbu gulai, rendang, tumisan, dan lain-lain

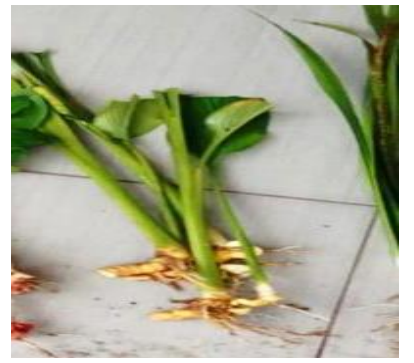

Gambar 6. Tanaman Kunyit Putih

Sumber: Dokumentasi Lapangan, 2020.

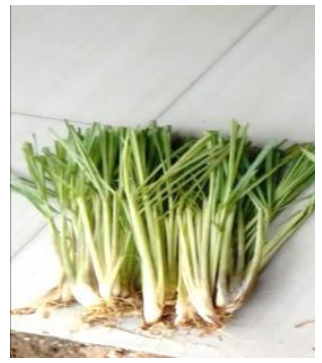

Gambar 7. Tanaman Serai Sumber: Dokumentasi Lapangan, 2020.

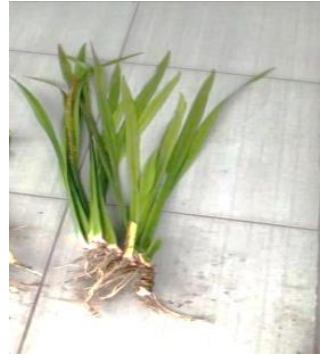

Gambar 8. Tanaman Jerangau

Sumber: Dokumentasi Lapangan, 2020.

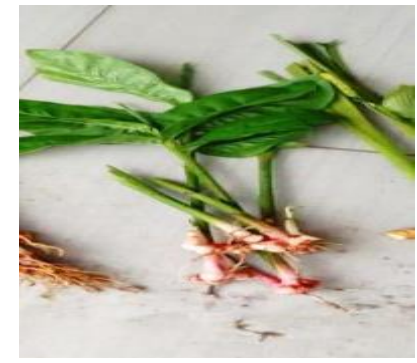

Gambar 9. Tanaman Kunyit Sumber: Dokumentasi Lapangan, 2020.

Meskipun bentuk program kegiatan terlihat sederhana tetapi dari segi manfaat penanaman TOGA juga sangat menguntungkan seperti yang telah dijelaskan sebelumnya. Berkaitan dengan hal tersebut indicator keberhasilan program yang kami lakukan dilihat dari tingginya partisipasi masyarakat untuk terlibat baik dalam perawatan komoditas lele dumbo maupun TOGA. Permintaan secara langsung kepada tim pengabdian dari masyarakat untuk memberikan pelatihan di kemudian hari mengenai bagaimana pengembangan komoditas tersebut menjadi indicator pencapaian keberhasilan program. Meskipun secara ekonomi belum terlihat akan tetapi secara individu mereka sudah memiliki keinginan untuk meneruskan budidaya menjadi pengelolaan.

\section{KESIMPULAN}

Secara umum kegiatan pengabdian di Kampung Rawa Mekar Jaya berjalan dengan lancar meskipun terdapat beberapa kendala yang diyakini oleh tim pengabdian juga dialami oleh tim lain di lokasi yang berbeda. Suasana pandemic covid-19 menyebabkan pergerakan menjadi lebih terbatas dan berdampak pada penyesuaian berbagai rencana aksi yang akan dilakukan. Di Rawa Mekar Jaya tim pengabdian mendorong ketahanan ekonomi rumah tangga dengan budidaya ikan lele dumbo dan tanaman obat keluarga atau TOGA. Budidaya lele dumbo dilakukan dengan media ember besar, terpal, dan kolam yang dimiliki masing-masing orang terpilih baik berasal dari bekas budidaya yang pernah mereka lakukan maupun dibuat seketika saat 
mendapatkan bibit. Meskipun kegiatan ini dilakukan dalam skala yang kecil tetapi harapan kami hal ini dapat mendorong kemadirian masyarakat untuk mengikuti hal serupa sesuai kemampuan masing-masing.

\section{Saran}

Pelaksanaan pengabdian ini masih memerlukan dukungan masyarakat dan pemerintah desa sehingga berkaitan dengan hal tersebut saran yang dapat kami berikan agar apa yang sudah dilakukan bersama dapat dilanjutkan serta bila memungkinkan untuk dikembangkan dalam skala yang luas sesuai kebutuhan dan kemampuan.

\section{UCAPAN TERIMAKASIH}

Tim pengabdian mengucapkan terimakasih kepada berbagai pihak yang telah membantu dalam kegiatan di lapangan diantaranya mahasiswa kukerta, pemerintah Kampung Rawa Mekar Jaya dan masyarakat. Terimakasih juga kami ucapkan kepada LPPM Universitas Riau yang telah memberikan kesempatan kepada tim kami melakukan pengabdian di lokasi yang sudah ditentukan.

\section{DAFTAR PUSTAKA}

Apriyana, I. 2014. Pengaruh Penambahan Tepung Kepala Ikan Lele (Carias sp) dalam Pembuatan Cilok Terhadap Kadar Protein dan Sifat Organoleptiknya. Unnes Jorunal of Public Health Vol. 3 No. 2, 1-9.

BPS, B. P. 2010 . Statistik Penduduk Kabupaten Siak. Jakarta, Jakarta, Indonesia.

Dewi, R. S. 2020 .m.goriau.com. Dipetik Juni 20, 2020, dari m.goriau.com: https://m.goriau.com

Fauziah, A. 2009. Pemberdayaan Masyarakat. Malang: Direktorat Pendidikan Tinggi Islam Depak.

Nugraha, S. P., \& Agustiningsih, W. R. 2015. Pelatihan Tanaman Obat Keluarga (TOGA). Inovasi dan Kewirausahaan. $4(1), 58-62$.

Prijono. 2001. Komunitas Pemberdayaan. Jakarta: Alfabeta.

Saturi, S. 2020 .mongabay.co.id. Dipetik Juni 20, 2020, dari mongabay.co.id: https://mongabay.co.id

Sinaga, F. A., Rosnita, \& Sayamar, E. 2016. Analisis Dinamika Kelompok Tani Sagu di Desa Lukun Kecamatan Tebing Tinggi Timur Kabupaten Kepulauan Meranti. JOM FAPERTA Universitas Riau Vol. 3 No. 2, 1-6.

Sulistiani, A. T. 2004. Kemitraan dan Model-Model Pemberdayaan. Yogyakarta: Gava Media.

Vidyandik, P. 1996. Proses Pemberdyaan Masyarakat. Bandung: Rajawali.

Zamakhsari, D. 1993. Tradusi Pesantren. Jakarta: PT. Matahari Bakti.

Zubaedy. 2013. Pengembangan Masyarakat dan Praktek. Jakarta: Kencana Prenanda Media Group. 